\title{
Cephalometric Norms for Indian Adults using Digital Posteroanterior Analysis
}

\author{
${ }^{1}$ David Marianayagam, ${ }^{2}$ Ashima Vallathan \\ ${ }^{1}$ Assistant Professor, Department of Orthodontics, Manipal College of Dental Sciences, Manipal, Karnataka, India \\ ${ }^{2}$ Professor and Head, Department of Orthodontics, Manipal College of Dental Sciences, Manipal, Karnataka, India
}

Correspondence: David Marianayagam, Assistant Professor, Department of Orthodontics, Manipal College of Dental Sciences Manipal, Karnataka, India, e-mail: davidmds@ rediffmail.com

\section{ABSTRACT}

Introduction: Facial and radiographic records in orthodontics are based on the profile. Aim of this study is to establish norms from digital posteroanterior (PA) cephalograms for Indian adults.

Materials and methods: The subjects included 45 Indian men and 55 Indian women, mean age 25 to 30 years. Subjects had ideal occlusion and a well-balanced face. About 12 linear measurements were determined using digital radiograph.

Results: There was statistically significant difference between male and female samples. Comparison between the Indian men and women indicated larger measurements for men.

Conclusion: According to these results new PA clinical norms are presented to Indian orthodontists for diagnosis and planning.

Abbreviations: ANS-Anterior nasal spine, A3-B3-Upper and lower canine right side, 3A-3B-Upper and lower canine left side Me-Menton.

Keywords: Digital cephalogram, Norms, Indian adults.

\section{INTRODUCTION}

A nthropometry is the measurement of living subjects. M any facial and radiographic records in orthodontics are based on the profile. Orthodontics is mainly concerned with esthetics. Symmetry plays a crucial role in esthetics, and it can be better assessed from the frontal view, since persons present to the world with their face forward.

The frontal view of the face and consequently posteroanterior (PA) cephal ograms should be an integral part of facial evaluation. In recent years, there has been a growing demand for PA cephalograms in the treatment of craniofacial anomalies. Different racial groups must be treated according to their own characteristics.

$V$ ery few studies have been undertaken to determine the Indian population's ideal norms.

Hence, it was decided to give ideal values using digital posteroanterior cephal ograms for the Indian adult population.

The most extensive data on the Indian adults so far has been reported by Farkas ${ }^{1}$ with 14 measurements which were recorded from various parts of the craniofacial complex.

The longitudinal assessment of craniofacial morphology is well recognized, and is now a universally used cephal ometric technique. Downs, ${ }^{2}$ Steiner and Tweed $^{3}$ developed cephalometric norms and analyses in an attempt to define skeletal characteristics of an ideal face and occlusion. The sample population consisted of white $\mathrm{N}$ orth A merican children and young adults with time; it became apparent that cephalometric standards for one ethnic group did not necessarily apply to the other ethnic groups.
PA cephalometric films can be analyzed to evaluate the vertical, transverse and sagittal dimensions. ${ }^{4} \mathrm{~V}$ arious dental and skel etal widths and skeletal asymmetries that are not available from the lateral cephalogram can be quantified from a frontal radiograph. ${ }^{5}$

\section{AIMS}

The aim of this study is to establish cephal ometric norms from digital posteroanterior cephal ograms for Indian adults to identify possible gender difference in these norms to compare Indian norms with the norms of other groups and to identify possible correlations between all investigated transverse linear measurements.

\section{MATERIALS AND METHODS}

This radiographic study was carried out in the Department of Orthodontics and D entofacial Orthopedics, $M$ anipal College of Dental Sciences, $M$ anipal. The study design was reviewed and approved by the Institutional Ethical Committee of our institution for study on human subjects (IEC 134/2009).

A total sample of 50 north Indian and 50 south Indian subjects was selected to find ethnic difference between them.

The subjects incl uded 45 Indian men (mean age, 25-30 years) and 55 Indian women (mean age, 25-30 years). A standard posteroanterior digital radiograph with teeth in centric occlusion and well-balanced face of each individual was done (Fig. 1). Twelve linear measurements were determined on each radiograph using digital radiograph (Fig. 2). The midline was measured from crista galli to the menton. 


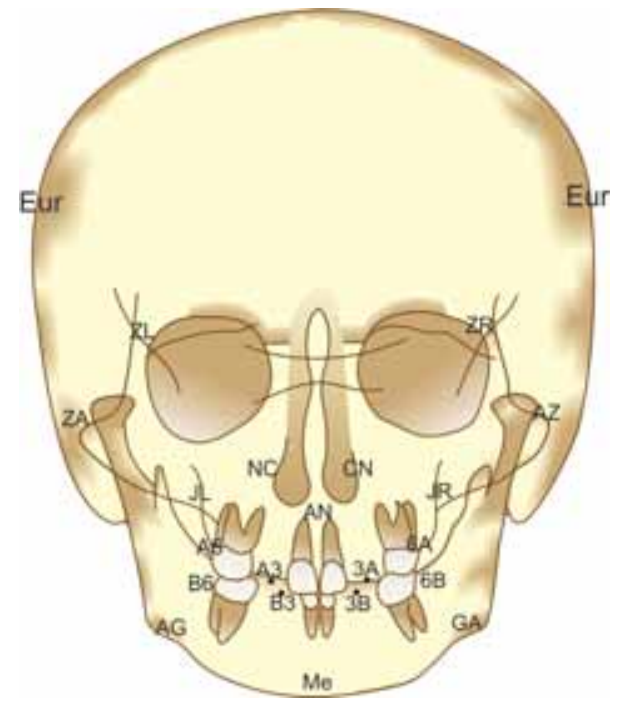

Fig. 1: Standard PA cephalogram

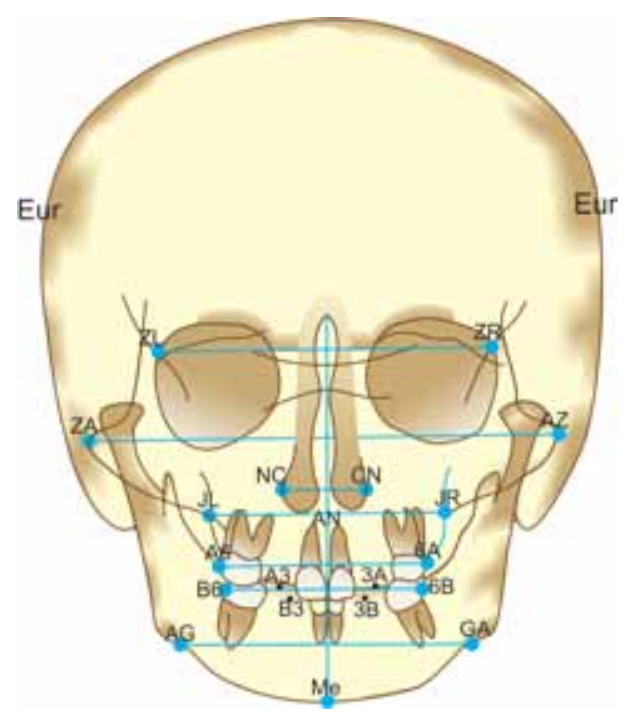

Fig. 2: Twelve linear measurements
There was no significant medical history; no history of trauma and any previous orthodontic or prosthodontic treatment or maxillofacial or plastic surgery. PA cephalograms were taken with the distance betw een the $X$-ray tube and the ear post axis fixed at 5 feet $(1.524 \mathrm{~m})$. A $n$ informed consent from each of the selected subjects was taken for roentgenography. The radiographic minification error was eliminated by standardizing the radiographs.

\section{Measurements}

1. Cranial width (Eur-Eur)

2. ZL-ZR

3. Facial width (ZA-AZ)

4. Nasal width (NC-CN)

5. M axillary width (JL-JR)

6. Mandibular width (A G-GA)

7. Maxillary intermolar width

8. M andibular intermolar width

9. $A 6-B 6$ difference

10. $6 \mathrm{~A}-6 \mathrm{~B}$ difference

11. U pper midline deviation

12. Lower midline deviation

$Z$ - superior aspect of the orbit

ZA-AZ (facial width) - width of the zygomatic arch at its lateral aspect.

\section{Method Error}

The accuracy of the measurements was evaluated by standardizing the radiographs using $1 \mathrm{~cm}$ of stainless steel wire while taking the radiographs on cranial, zygomatic, maxillary and mandibular region of the face. Formula used (for a minification image), actual image $=$ object image $x$ magnification factor.

\section{STATISTICS}

The cephalograms obtained from the Kodak digital X-ray machine were measured using $K$ odak dental imaging software 6.6. All statistical analyses were performed with a commercial software package (Statistical Package for Social Sciences for Windows 2007, version 11.5; SPSS,Chicago, III).

For the assessment of the difference between the south Indian and north Indian population, paired t-test was used. For each variable, the arithmetic mean, the standard deviation, and the minimum and maximum values were calculated. A $n$ independent-samples t-test and the Pearson product-moment correl ation coefficient were decided to indicate the relationship between all investigated linear dimensions.

\section{RESULTS}

There was no statistically significant difference found between the south Indian and north Indian samples for the parameters used; therefore, both the samples were clubbed together for this study (Table 1).

The structures located in the PA cephalometric analysis were generally well visualized on the digital cephalograms. Table 2 shows the PA cephalometric combined norms, standard deviations, and minimum and maximum values of 12 linear transverse measurements for Indian adults. The following results were obtained through the independent-samples t-test applied to compare the measurement differences between men and women. Tables 3 and 4 present the descriptive statistic results of the measurements for the samples of adult Indian women and men respectively.

These results were obtained through the independentsamples t-test applied to compare the measurement differences between men and women. M ale samples had higher value than the female samples. 
Cephalometric Norms for Indian Adults using Digital Posteroanterior Analysis

\begin{tabular}{|c|c|c|c|c|c|}
\hline & NISI & $\mathrm{N}$ & Mean & Std. deviation & p-value \\
\hline Cranial width & $\begin{array}{l}1.00 \\
2.00\end{array}$ & $\begin{array}{l}49 \\
50\end{array}$ & $\begin{array}{l}139.686 \\
137.490\end{array}$ & $\begin{array}{l}7.5026 \\
7.4207\end{array}$ & 0.146 \\
\hline ZL-ZR & $\begin{array}{l}1.00 \\
2.00\end{array}$ & $\begin{array}{l}49 \\
50\end{array}$ & $\begin{array}{l}87.061 \\
88.186\end{array}$ & $\begin{array}{l}5.2771 \\
3.7225\end{array}$ & 0.223 \\
\hline Facial width & $\begin{array}{l}1.00 \\
2.00\end{array}$ & $\begin{array}{l}49 \\
50\end{array}$ & $\begin{array}{l}129.563 \\
128.384\end{array}$ & $\begin{array}{l}6.6676 \\
5.8000\end{array}$ & 0.350 \\
\hline Nasal width & $\begin{array}{l}1.00 \\
2.00\end{array}$ & $\begin{array}{l}49 \\
50\end{array}$ & $\begin{array}{l}33.641 \\
33.710\end{array}$ & $\begin{array}{l}2.6553 \\
3.1815\end{array}$ & 0.907 \\
\hline Max. width & $\begin{array}{l}1.00 \\
2.00\end{array}$ & $\begin{array}{l}49 \\
50\end{array}$ & $\begin{array}{l}62.684 \\
62.614\end{array}$ & $\begin{array}{l}5.1758 \\
3.3929\end{array}$ & 0.937 \\
\hline Mand. width & $\begin{array}{l}1.00 \\
2.00\end{array}$ & $\begin{array}{l}49 \\
50\end{array}$ & $\begin{array}{l}86.606 \\
85.696\end{array}$ & $\begin{array}{l}7.3536 \\
6.1168\end{array}$ & 0.504 \\
\hline Max. int. width & $\begin{array}{l}1.00 \\
2.00\end{array}$ & $\begin{array}{l}49 \\
50\end{array}$ & $\begin{array}{l}62.753 \\
62.674\end{array}$ & $\begin{array}{l}3.5601 \\
3.2841\end{array}$ & 0.909 \\
\hline Mand. int. width & $\begin{array}{l}1.00 \\
2.00\end{array}$ & $\begin{array}{l}49 \\
50\end{array}$ & $\begin{array}{l}52.543 \\
54.382\end{array}$ & $\begin{array}{l}5.6653 \\
5.2281\end{array}$ & 0.096 \\
\hline A6-B 6 & $\begin{array}{l}1.00 \\
2.00\end{array}$ & $\begin{array}{l}49 \\
50\end{array}$ & $\begin{array}{l}12.847 \\
11.842\end{array}$ & $\begin{array}{l}7.9584 \\
2.2223\end{array}$ & 0.392 \\
\hline $6 A-6 B$ & $\begin{array}{l}1.00 \\
2.00\end{array}$ & $\begin{array}{l}49 \\
50\end{array}$ & $\begin{array}{l}11.839 \\
10.846\end{array}$ & $\begin{array}{l}7.1989 \\
2.0935\end{array}$ & 0.352 \\
\hline Upper midline & $\begin{array}{l}1.00 \\
2.00\end{array}$ & $\begin{array}{l}49 \\
50\end{array}$ & $\begin{array}{l}1.567 \\
1.544\end{array}$ & $\begin{array}{l}0.9698 \\
0.6923\end{array}$ & 0.890 \\
\hline Lower midline & $\begin{array}{l}1.00 \\
2.00\end{array}$ & $\begin{array}{l}49 \\
50\end{array}$ & $\begin{array}{l}1.490 \\
1.456\end{array}$ & $\begin{array}{l}0.8912 \\
0.8011\end{array}$ & 0.843 \\
\hline
\end{tabular}

Table 2: Descriptive statistics of PA cephalometric measurements (in millimeters) for 100 Indian adults

\begin{tabular}{lrrrrr} 
& $N$ & Minimum & Maximum & Mean & Std. deviation \\
\hline Cranial width & 100 & 122.3 & 162.8 & 138.712 & 7.5134 \\
ZL-ZR & 100 & 73.3 & 100.3 & 87.622 & 4.5414 \\
Facial width & 100 & 115.9 & 143.5 & 129.037 & 6.2490 \\
Nasal width & 100 & 26.7 & 44.8 & 33.689 & 2.9304 \\
Max. width & 100 & 36.7 & 70.7 & 62.708 & 4.3392 \\
Mand. width & 100 & 56.9 & 100.6 & 86.177 & 6.7272 \\
Max. int. width & 100 & 55.8 & 70.0 & 62.741 & 3.3998 \\
Mand. int. width & 100 & 43.0 & 73.0 & 53.530 & 5.5020 \\
A6-B6 & 100 & 9.0 & 66.0 & 12.290 & 5.7880 \\
6A-6B & 100 & 7.0 & 59.4 & 11.333 & 5.2484 \\
Upper midline & 100 & 0.0 & 4.2 & 1.527 & 0.8322 \\
Lower midline & 100 & 0.0 & 3.8 & 1.443 & 0.8362 \\
Valid N (listwise) & 100 & & & &
\end{tabular}

Of the 12 craniofacial transverse measurements, there was statistically significant difference found in the cranial width, facial width, maxillary width, mandibular width and maxillary intermolar width for male and female samples (Table 5). Comparison between the Indian men and women indicated larger measurements for men in all investigated linear transverse measurements.

To study the correlations between each of the 12 measurements, Pearson correlation coefficients were calculated and have been shown in Table 6.

The interexaminer errors of measurements for several distances were less than $0.5 \mathrm{~mm}$, and the corresponding intraclass correlation coefficients were greater than $r=0.98$.

\section{DISCUSSION}

This study is the first to investigate samples of untreated Indian adults with ideal occlusion and well-balanced faces. The inclusion criteria and methodology were oriented to identify normative values that can assist in the diagnosis and treatment planning of Indian adults seeking orthodontic treatment or orthognathic surgery. A dults 25 to 30 years of age of both sexes were included in the sample because most orthognathic surgeries are performed in this age group.

$M$ any articles have been published concerning normative data related to facial structures studied with lateral cephalometry; however, publications describing the use of PA 
Table 3: Descriptive statistics of PA cephalometric measurements (in millimeters) for 55 Indian women

\begin{tabular}{lrrrrr} 
& N & Minimum & Maximum & Mean & Std. deviation \\
\hline Cranial width & 55 & 122.3 & 150.4 & 136.498 & 6.8498 \\
ZL-ZR & 55 & 77.5 & 100.3 & 87.349 & 3.9984 \\
Facial width & 55 & 115.9 & 138.3 & 126.496 & 6.0603 \\
Nasal width & 55 & 26.7 & 44.8 & 33.607 & 3.2614 \\
Max. width & 55 & 55.1 & 69.9 & 61.824 & 3.3905 \\
Mand. width & 55 & 59.0 & 94.0 & 84.442 & 5.8908 \\
Max. int. width & 55 & 55.8 & 69.6 & 61.760 & 3.3574 \\
Mand. int. width & 55 & 43.0 & 72.0 & 52.890 & 5.4230 \\
A6-B6 & 55 & 9.0 & 15.0 & 11.410 & 1.6620 \\
6A-6B & 55 & 7.0 & 14.9 & 10.498 & 1.6821 \\
Upper midline & 55 & 0.3 & 3.2 & 1.522 & 0.7443 \\
Lower midline & 55 & 0.3 & 3.8 & 1.464 & 0.8061
\end{tabular}

Table 4: Descriptive statistics of PA cephalometric measurements (in millimeters) for 45 Indian men

\begin{tabular}{lrrrrr} 
& N & Minimum & Maximum & Mean & Std. deviation \\
\hline Cranial width & 45 & 127.4 & 162.8 & 141.418 & 7.4712 \\
ZL-ZR & 45 & 73.3 & 95.6 & 87.956 & 5.1554 \\
Facial width & 45 & 120.9 & 143.5 & 132.142 & 4.9859 \\
Nasal width & 45 & 28.5 & 39.2 & 33.789 & 2.4996 \\
Max. width & 45 & 36.7 & 70.7 & 63.789 & 5.1072 \\
Mand. width & 45 & 56.9 & 100.6 & 88.298 & 7.1325 \\
Max. int. width & 45 & 56.7 & 70.0 & 63.940 & 3.0820 \\
Mand. int. width & 45 & 44.0 & 73.0 & 54.320 & 5.5570 \\
A6-B6 & 45 & 9.0 & 66.0 & 13.360 & 8.3580 \\
6A-6B & 45 & 7.7 & 59.4 & 12.353 & 7.5213 \\
Upper midline & 45 & 0.0 & 4.2 & 1.533 & 0.9371 \\
Lower midline & 45 & 0.0 & 3.1 & 1.418 & 0.8802
\end{tabular}

cephalograms are relatively few. ${ }^{6-23}$ A ttempts have been made to investigate the differences of the human face among various ethnic groups, including A frican-A mericans, A fricans, C hinese, Japanese, Koreans, Indians, Saudi Arabians, MexicanA mericans, B razilians and Puerto R icans. In a comparative study of Japanese and European-A merican adults, M iyajima et al reported greater ethnic differences in soft tissue relationships than in skeletal and dentitional relationships. The issue of soft tissue profiles, however, played a small part in the majority of the studies mentioned above. ${ }^{6-22}$

A thanasiou ${ }^{24}$ indicated that all existing cephalometric data are of value for the diagnosis of various types of craniofacial anomal ies and for monitoring groups according to age and race.

Studies describing the use of PA cephalograms are relatively few. ${ }^{4,25-31}$ Recently, there has been a growing demand for extended roentgenocephal ometric control material, because of refinements in syndrome identification and advances in the treatment of craniofacial anomalies. ${ }^{21}$

George P Thomas, V aliathan A shima, et $\mathrm{al}^{30}$ in 2000, assessed the asymmetry between the right and left side of the face of the south Indian with clinically symmetrical and pleasing facial features and normal occlusion. The facial areas were studied separately and a comparison between the north and south Indians were made and it was found that the south Indians appeared to have a more prominent lateral maxillary area, cranial base and dentoalveolar regions than north Indians. There was no significant difference between north and south Indians, the overall structure appeared similar. Taking the result into consideration, the norms for Indian adults have been planned using the digital posteroanterior analysis.

M oyers et $\mathrm{al}^{29}$ presented valuable normative data derived from the University of $\mathrm{M}$ ichigan study. W ei ${ }^{31}$ produced PA cephalometric normative data for $C$ hinese subjects after examining 84 boys and 22 girls. W ith a similar aim, this study was carried out to establish cephal ometric normative data from digital PA cephalograms for Indian adults.

WC N geow et al ${ }^{32}$ found that males in general have higher measurement than females for the $\mathrm{M}$ alaysian Indian population. In our study also we found that males had higher values than female subjects.

In our study, we used PA cephalometric analysis measurements of Ricketts et $\mathrm{al}^{33}$ to determine the normative data for Indian adults. A mong several analyses, ${ }^{34-37}$ the method of Ricketts et al $^{33}$ seems to be the most widely used, perhaps because it provides normative values for different ages.

Ricketts et $\mathrm{al}^{33}$ found facial width (ZA-A Z) to have a mean value of $115.7 \mathrm{~mm}$ at the age of 9 years, with $2.4 \mathrm{~mm}$ increase per year; the ZA -A Z measurement was $137.3 \mathrm{~mm}$ for an adult, according to their prediction (nearly at age 18). In the present study, this measurement was $129.0 \mathrm{~mm}$, which shows that the facial width is narrower than the clinical norm of Ricketts et al and Turkish adults (139.62 \pm 7.25$)$.

Ricketts et $\mathrm{al}^{33}$ found that the width of the maxilla (J L-JR) was $61.9 \mathrm{~mm}$ for a 9-year-old subject and increased $0.6 \mathrm{~mm}$ 
Cephalometric Norms for Indian Adults using Digital Posteroanterior Analysis

Table 5: Comparison of means and standard deviations of PA cephalometric measurements (in millimeters) between 45 men and 55 women

\begin{tabular}{|c|c|c|c|c|c|}
\hline & Sex & $\mathrm{N}$ & Mean & Std. deviation & $\mathrm{p}$-value \\
\hline Cranial width & $\begin{array}{r}\text { Male } \\
\text { Female }\end{array}$ & $\begin{array}{l}45 \\
55\end{array}$ & $\begin{array}{l}141.418 \\
136.498\end{array}$ & $\begin{array}{l}7.4712 \\
6.8498\end{array}$ & 0.001 \\
\hline ZL-ZR & $\begin{array}{r}\text { Male } \\
\text { Female }\end{array}$ & $\begin{array}{l}45 \\
55\end{array}$ & $\begin{array}{l}87.956 \\
87.349\end{array}$ & $\begin{array}{l}5.1554 \\
3.9984\end{array}$ & 0.509 \\
\hline Facial width & $\begin{array}{r}\text { Male } \\
\text { Female }\end{array}$ & $\begin{array}{l}45 \\
55\end{array}$ & $\begin{array}{l}132.142 \\
126.496\end{array}$ & $\begin{array}{l}4.9859 \\
6.0603\end{array}$ & 0.000 \\
\hline Nasal width & $\begin{array}{r}\text { Male } \\
\text { Female }\end{array}$ & $\begin{array}{l}45 \\
55\end{array}$ & $\begin{array}{l}33.789 \\
33.607\end{array}$ & $\begin{array}{l}2.4996 \\
3.2614\end{array}$ & 0.760 \\
\hline Max. width & $\begin{array}{r}\text { Male } \\
\text { Female }\end{array}$ & $\begin{array}{l}45 \\
55\end{array}$ & $\begin{array}{l}63.789 \\
61.824\end{array}$ & $\begin{array}{l}5.1072 \\
3.3905\end{array}$ & 0.023 \\
\hline Mand. width & $\begin{array}{r}\text { Male } \\
\text { Female }\end{array}$ & $\begin{array}{l}45 \\
55\end{array}$ & $\begin{array}{l}88.298 \\
84.442\end{array}$ & $\begin{array}{l}7.1325 \\
5.8908\end{array}$ & 0.004 \\
\hline Max. int. width & $\begin{array}{r}\text { Male } \\
\text { Female }\end{array}$ & $\begin{array}{l}45 \\
55\end{array}$ & $\begin{array}{l}63.940 \\
61.760\end{array}$ & $\begin{array}{l}3.0820 \\
3.3574\end{array}$ & 0.001 \\
\hline Mand. int. width & $\begin{array}{r}\text { Male } \\
\text { Female }\end{array}$ & $\begin{array}{l}45 \\
55\end{array}$ & $\begin{array}{l}54.32 \\
52.89\end{array}$ & $\begin{array}{l}5.557 \\
5.423\end{array}$ & 0.197 \\
\hline A6-B 6 & $\begin{array}{r}\text { Male } \\
\text { Female }\end{array}$ & $\begin{array}{l}45 \\
55\end{array}$ & $\begin{array}{l}13.36 \\
11.41\end{array}$ & $\begin{array}{l}8.358 \\
1.662\end{array}$ & 0.095 \\
\hline $6 A-6 B$ & $\begin{array}{r}\text { Male } \\
\text { Female }\end{array}$ & $\begin{array}{l}45 \\
55\end{array}$ & $\begin{array}{l}12.353 \\
10.498\end{array}$ & $\begin{array}{l}7.5213 \\
1.6821\end{array}$ & 0.079 \\
\hline Upper midline & $\begin{array}{r}\text { Male } \\
\text { Female }\end{array}$ & $\begin{array}{l}45 \\
55\end{array}$ & $\begin{array}{l}1.533 \\
1.522\end{array}$ & $\begin{array}{l}0.9371 \\
0.7433\end{array}$ & 0.946 \\
\hline Lower midline & $\begin{array}{r}\text { Male } \\
\text { Female }\end{array}$ & $\begin{array}{l}45 \\
55\end{array}$ & $\begin{array}{l}1.418 \\
1.464\end{array}$ & $\begin{array}{l}0.8802 \\
0.8061\end{array}$ & 0.787 \\
\hline
\end{tabular}

Table 6: Correlation coefficients of all parameters

\begin{tabular}{|c|c|c|c|c|c|c|c|c|c|c|c|c|}
\hline & $\begin{array}{l}\text { Cranial } \\
\text { width }\end{array}$ & ZL-ZR & $\begin{array}{l}\text { Facial } \\
\text { width }\end{array}$ & $\begin{array}{l}\text { Nasal } \\
\text { width }\end{array}$ & $\begin{array}{l}\text { Max. } \\
\text { width }\end{array}$ & $\begin{array}{l}\text { Mand. } \\
\text { width }\end{array}$ & $\begin{array}{l}\text { Max. int. } \\
\text { width }\end{array}$ & $\begin{array}{l}\text { Mand. } \\
\text { int. width }\end{array}$ & $\begin{array}{l}\text { A6-B6 } \\
\text { width }\end{array}$ & $\begin{array}{l}6 \mathrm{~A}-6 \mathrm{~B} \\
\text { width }\end{array}$ & $\begin{array}{l}\text { Upper } \\
\text { midline }\end{array}$ & $\begin{array}{l}\text { Lower } \\
\text { midline }\end{array}$ \\
\hline $\begin{array}{l}\text { Cranial } \\
\text { width }\end{array}$ & 1 & $0.427^{* *}$ & $0.536 * *$ & 0.075 & 0.128 & $0.344 * *$ & $0.304 * *$ & $0.264 * *$ & 0.134 & 0.160 & 0.162 & 0.121 \\
\hline ZL-ZR & $0.427 * *$ & 1 & $0.461^{* *}$ & $0.320 * *$ & 0.189 & $0.321^{* *}$ & $0.209 *$ & 0.147 & 0.028 & 0.050 & 0.045 & 0.023 \\
\hline $\begin{array}{l}\text { Facial width } \\
\text { Nasal width }\end{array}$ & $\begin{array}{l}0.536 \text { ** } \\
0.075\end{array}$ & $\begin{array}{l}0.461^{* *} \\
0.320^{* *}\end{array}$ & $\begin{array}{l}1 \\
0.324 * *\end{array}$ & $\begin{array}{l}0.324 * * \\
1\end{array}$ & $\begin{array}{l}0.410^{* *} \\
0.393^{* *}\end{array}$ & $\begin{array}{l}0.474 * * \\
0.194\end{array}$ & $\begin{array}{l}0.429 * * \\
0.259 * *\end{array}$ & $\begin{array}{l}0.200 * \\
0.045\end{array}$ & $\begin{array}{l}0.131 \\
0.022\end{array}$ & $\begin{array}{l}0.141 \\
-0.007\end{array}$ & $\begin{array}{l}0.146 \\
0.117\end{array}$ & $\begin{array}{l}0.122 \\
0.151\end{array}$ \\
\hline Max. width & 0.128 & 0.189 & $0.410 * *$ & $0.393^{* *}$ & 1 & $0.261^{* *}$ & $0.495 * *$ & $0.217^{*}$ & 0.164 & 0.119 & -0.035 & -0.066 \\
\hline $\begin{array}{l}\text { Mand. width } \\
\text { Max. int. width }\end{array}$ & $\begin{array}{l}0.344^{* *} \\
0.304^{* *}\end{array}$ & $\begin{array}{l}0.321 * * \\
0.209 *\end{array}$ & $\begin{array}{l}0.474 * * \\
0.429 * *\end{array}$ & $\begin{array}{l}0.194 \\
0.259 * *\end{array}$ & $\begin{array}{l}0.261^{* *} \\
0.495^{* *}\end{array}$ & $\begin{array}{l}1 \\
0.414 * *\end{array}$ & $\begin{array}{l}0.414 * * \\
1\end{array}$ & $\begin{array}{l}0.226 * \\
0.514 * *\end{array}$ & $\begin{array}{l}0.058 \\
0.187\end{array}$ & $\begin{array}{l}0.073 \\
0.172\end{array}$ & $\begin{array}{l}-0.003 \\
0.087\end{array}$ & $\begin{array}{l}-0.018 \\
0.137\end{array}$ \\
\hline Mand. int width & $0.264^{* *}$ & 0.147 & $0.200 *$ & 0.045 & $0.217^{*}$ & $0.226^{*}$ & $0.514^{* *}$ & 1 & 0.043 & 0.075 & 0.073 & 0.078 \\
\hline$A 6-B 6$ & 0.134 & 0.028 & 0.131 & 0.022 & 0.164 & 0.058 & 0.187 & 0.043 & 1 & $0.977 * *$ & -0.128 & -0.066 \\
\hline $6 A-6 B$ & 0.160 & 0.050 & 0.141 & -0.007 & 0.119 & 0.073 & 0.172 & 0.075 & $0.977^{* *}$ & 1 & -0.108 & -0.059 \\
\hline Upper midline & 0.162 & 0.045 & 0.146 & 0.117 & -0.035 & -0.003 & 0.087 & 0.073 & -0.128 & -0.108 & 1 & $0.883^{* *}$ \\
\hline Lower midline & 0.121 & 0.023 & 0.122 & 0.151 & -0.066 & -0.018 & 0.137 & 0.078 & -0.066 & -0.059 & $0.883^{* *}$ & 1 \\
\hline
\end{tabular}

**Correlation is significant at the 0.01 level (2-tailed)

*Correlation is significant at the 0.05 level (2-tailed)

per year. A ccording to them, at age 18 , the $J \mathrm{~L}-\mathrm{J} R$ distance is approximately $67.3 \mathrm{~mm}$. In the present study, the mean J L -J R distance was $61.8 \pm 3.3 \mathrm{~mm}$ for women and $63.8 \pm 5.10 \mathrm{~mm}$ for men, not much different from the Turkish study which shows $63.81 \pm 3.33$ for women and $69.86 \pm 4.30$ for men respectively.
The Bolton study group value was J L-JR distance of $64.7 \pm$ $2.7 \mathrm{~mm}$ which is similar to the results of our study.

Ricketts et $\mathrm{al}^{33}$ found that mandibular width, as measured from the antegonial notch points (AG-GA), had a norm of $76.1 \mathrm{~mm}$ at age 9 years and increased $1.4 \mathrm{~mm}$ per year. 
A ccording to them, the A G-GA distance is approximately 88.7 $\mathrm{mm}$ for a young adult. Similarly, Cortella et al ${ }^{4}$ determined PA cephalometric norms from the Bolton Study Group for A G$G A$ and JL-JR distances for a young adult population. They reported an A G-GA distance of $86.4 \pm 4.5 \mathrm{~mm}$ and also in the Turkish adult population the (AG-GA) width was $98.03 \pm$ $7.36 \mathrm{~mm}$. In our study it was $88.2 \pm 7.1$, showing a narrower width.

Ricketts et $a^{33}$ found nasal width (NC-CN) to have a mean of $25 \mathrm{~mm}$ for the 9-year-old subject, increasing $0.7 \mathrm{~mm}$ per year. The NC-CN measurement was approximately $31.3 \mathrm{~mm}$ for an adult (at age 18). M easurement of $32.4 \mathrm{~mm}$ was found for the Turkish adults similar to the measurement found in our study $(33.689 \pm 2.9)$.

Snodell et a ${ }^{27}$ indicated that there is an average increase in maxillary intermolar width (A 6-6A) of $1.4 \mathrm{~mm}$ from 16 to 18 years for boys. They stated that, after age 18 , insignificant grow th changes occur in A 6-6A distances. Tancan U ysal et a ${ }^{23}$ showed that in the Turkish adults the intermolar distance norm value was $61.17 \pm 3.45 \mathrm{~mm}$. In our study, this measurement was similar (62.7-3.4 mm) in Indian adults.

M eredith ${ }^{38}$ found that male subjects had greater facial widths than female subjects for each age group studied. In the current study, the data were separated according to sex to obtain more specific and useful cephalometric normative values; not surprisingly, the sexual dimorphism was found to be significant for 12 transverse linear measurements, not including the $6 \mathrm{~A}$ $6 \mathrm{~B}$ difference, and the lower midline deviation. A dditionally, comparison between Indian men and women indicated larger measurements for men in all linear transverse measurements.

$N$ asal width was correlated with maxillary width $(r=0.339$, $p<0.01$ ), indicating a relationship between the airway and the width of the maxilla. M axillary width correlated with all dental width measurements. All dental width measurements were highly correlated with each other. Significant correlation coefficients between jaw and arch widths were determined. A Imost all correlation findings were narrower to those of T ancan Uysala et al. ${ }^{23}$

In our study, the facial width was significantly correlated with the cranial width $(r=0.53), Z L-Z R(r=0.46)$, nasal width $(r=0.32)$, maxillary width $(r=0.41)$, mandibular width $(r=0.47)$, maxillary intermolar $(r=0.42)$, mandibular intermolar width $(r=0.2)$.

M axillary intermolar width was significantly correlated with all the skeletal parameters and al so mandibular intermolar width $(p<0.05)$. This finding might conceptually support the functional matrix premise of functional requirements influencing optimal form. ${ }^{39}$

\section{CONCLUSION}

PA transverse linear norms for Indian adults were determined. In general, most measurements were narrower to Ricketts' clinical norms and also Turkish norms. PA cephalometric standards for Indian adults were also determined. The results of this study have clinical implications in the diagnosis and treatment planning of Indian patients. M ost of the Indian PA cephalometric linear measurements showed statistically significant sex differences. Comparisons between Indian men and women indicated higher measurements for men in all linear transverse measurements.

Cephal ometric values measured in this study will be useful for the treatment planning and also assessment of facial measurements for orthognathic cases. However, it is not the purpose of these normal data to be used as a template. Orthodontic and orthognathic treatments should always be planned according to each patient's needs and desires.

According to these results, new PA clinical norms are presented to Indian orthodontists for diagnosis and the planning of orthodontic treatment and orthognathic surgery.

\section{REFERENCES}

1. Farkas L G, Katic M J, Forest CR, A It WK, B agic I, B altadjiev $C$, et al. International anthropometric study of facial morphology in various ethnic groups/races. J Craniofacial Surg 2005;16: 615-46.

2. DownsW B. V ariation in the facial relationship their significance in treatment and prognosis. A merican Journal of Orthodontic 1948;34:812-40.

3. Steiner, Tweed $\mathrm{CH}$. The frankfort mandibular incisal angle (FMIA) in orthodontic diagnosis treatment planning and prognosis. A ngle orthodontist 1954;24:121-69.

4. Cortella S, Shofer FS, Ghafari J. Transverse development of the jaws: Norms for the posteroanterior cephal ometric analysis. A m J Orthod Dentofacial Orthop 1997;112:519-22.

5. Snodell SF, N anda RS, Currier GF. A longitudinal cephalometric study of transverse and vertical craniofacial growth. A m J Orthod Dentofacial Orthop 1993;104:471-83.

6. Cotton W N, Takano W S, Wong WM. The Downs analysis applied to three other ethnic groups. Angle Orthod 1951;21: 213-20.

7. Drummond RA. A determination of cephalometric norms for the Negro race. A m J Orthod 1968;54:670-82.

8. Connor AM, Moshiri R. Orthognathic surgery norms for A merican black patients. A m J Orthod 1985;87:119-34.

9. Flynn TR, A mbrogio RI, Zeichner SJ . Cephalometric norms for orthognathic surgery in black A merican adults. J Oral M axillofac Surg 1989;47:30-39.

10. Faustini M M, Hale C, Cisneros GJ. M esh diagram analysis: Developing a norm for A frican A mericans. Angle Orthod 1997;67:121-28.

11. Lee JJ, Ramirez SG, Will M J. Gender and racial variations in cephalometric analysis. Otolaryngol Head Neck Surg 1997;117:326-29.

12. Bacon W, Girardin P, Turl ot J C. A comparison of cephalometric norms for the A frican B antu and a caucasoid population. Eur J Orthod 1983;5:233-40.

13. Kapila S. Selected cephalometric norms in Kikuyu children. Anglen Orthod 1989;59:139-44.

14. Y en PK. The facial configuration in a sample of $\mathrm{C}$ hinese boys. Angle Orthod 1973;43:301-04.

15. Cooke M S, W ei SHY . A comparative study of southern Chinese and B ritish Caucasian cephalometric standards. A ngle Orthod 1989;59:131-38. 
16. U esato G, K inoshita Z, Kawamoto T, K oyama I, N akanishi Y. Steiner cephalometric norms for Japanese and J apaneseA mericans. A m J Orthod 1978;73:321-27.

17. Engel G, Spolter BM. Cephalometric and visual norms for a Japanese population. A m J Orthod 1981;80:48-60.

18. M iyajima K, M cNamara J A J r, K imura T, M urata S, lizuka T. Craniofacial structure of Japanese and European-A merican adults with normal occlusions and well-balanced faces. A m J Orthod Dentofacial Orthop 1996;110:431-38.

19. Alcalde RE, J inno T, Pogrel M A, M atsumura T. Cephalometric norms in Japanese adults. J Oral Maxillofac Surg 1998;56: 129-34.

20. Nanda R, Nanda RS. Cephalometric study of the dentofacial complex of north Indians. A ngle Orthod 1969;39:22-28.

21. Shalhoub SY, Sarhan OA, Shaikh HS. A dult cephalometric norms for Saudi A rabians with a comparison of values for Saudi and $\mathrm{N}$ orth A merican Caucasians. B J Orthod 1987;14:273-79.

22. Evanko A M , Freeman K, Cisneros GJ. M esh diagram analysis: Developing a norm for Puerto Rican A mericans. A ngle Orthod 1997;67:381-88.

23. Tancan Uysal, Zafer Sari. Posteroanterior cephalometric norms in Turkish adults. A m J Orthod Dentofacial Orthop 2005; 127:324-32.

24. A thanasiou A E. Orthodontic cephal ometry. Saint L ouis: M osby Wolf 1997.

25. Huertas D, G hafari J . N ew posteroanterior cephalometric norms: A comparison with craniofacial measures of children treated with palatal expansion. A ngle Orthod 2001;71:285-92.

26. Grummons DC, V an de Copello MAK. A frontal asymmetry analysis. J Clin Orthod 1987;21:448-65.

27. Snodell SF, N anda RS, Currier GF . A Iongitudinal cephal ometric study of transverse and vertical craniofacial growth. A m J Orthod Dentofacial Orthop 1993;104:471-83.
28. Broadbent BH Sr, Broadbent BH Jr, Golden WH. Bolton standards of dentofacial development and growth. Saint L ouis: M osby 1975.

29. M oyers RE, V an der Linden F, Riolo ML, M cNamara JA. Standards of human occlusal devel opment. Craniofacial G rowth Series. A nn A rbor: Center for Human Growth and Development U niversity of M ichigan 1976.

30. G eorge P Thomas, V aliathan A shima, Priya Padma. A Poaterioantrior cephal ometric study of bilateral facial asymmetry. JPFA J une 2000;14:53-59.

31. Wei S. Craniofacial width dimensions. Angle Orthod 1970;40:141-47.

32. N geow WC, A ijunid ST. Craniofacial anthropometric norms of M alaysian Indians. Indian J Dental Res 2009;20(3):313-19.

33. Ricketts RM, R oth RH, Chaconas SJ, Schulhof SJ, Engel GA. Orthodontic diagnosis and planning: Their roles in preventive and rehabilitative dentistry (Volume 1 ). Denver: Rocky M ountain Data Systems 1982;15-47.

34. Peck S, Peck L, K ataja M. Skeletal asymmetry in esthetically pleasing faces. A ngle Orthodontist 1991;61:43-47.

35. Lux, et al. Three-dimensional analysis of maxillary and mandibular growth increments cleft palate. Craniofacial J ournal M ay 2004;41(3).

36. Broadbent $B H$. A new $X$-ray technique and its application to orthodontia. A ngle orthod 1931;1:45-66.

37. B aumrind, M offit, C urry. Three-dimentional X-ray stereometry from paired coplanar images: A progree report. A m J Dentofac Orthop 1983;84:292-12.

38. M eredith HV. Growth in bizygomatic face breadth during childhood. Growth 1954;18:111-34.

39. Moss ML. The primary role of functional matrices in facial growth. A m J Orthod 1969;55:566-77. 